\title{
Przestępstwo naruszenia autorskich praw osobistych z art. 115 ust. 3 Ustawy z dnia 4 lutego 1994 r. o prawie autorskim i prawach pokrewnych w świetle zasady określoności
}

\section{Wprowadzenie}

Ustawa z dnia 4 lutego 1994 r. o prawie autorskim i prawach pokrewnych ${ }^{1}$, normująca podstawową problematykę związaną z ochroną praw autorskich, przynależy do systemu prawa prywatnego. Jej celem jest ochrona jednostki, przede wszystkim twórcy. Zawiera jednak przepisy karne, które przynależą do systemu prawa publicznego (ochrona interesu publicznego). W chwili obecnej systemowy podział na prawo publiczne i prywatne jest coraz mniej wyraźny ze względu na przenikanie się dziedzin prawa przynależnych do obu systemów². Stwierdzenie to ma znaczenie dla rozważań podjętych w niniejszym artykule wobec ustawowego sposobu penalizacji określonych zachowań zawarty w przepisach Prawa autorskiego. Przepisy karne zawarte w tej ustawie, a zatem przynależne systemowo do prawa publicznego, chronią interes publiczny. Jednocześnie jednak w dyspozycji tych przepisów zawarte są odesłania do przepisów ustawy regulujących zakres ochrony praw autorskich, tj. norm prawa prywatnego. Takie odesłanie, w kontekście wymogów, jakie powinny spełniać przepisy prawa karnego, budzi

${ }^{1}$ Tekst jedn. Dz.U. 2017, poz. 880, dalej „pr. aut.”.

2 Zob. M. Rogacka-Rzewnicka, O zjawisku "prywatyzacji” ("cywilizacji”) prawa karnego w świetle koncepcji celu postępowania karnego. Krótki rys historyczny, "Prokuratura i Prawo" 2010, nr 1-2, s. 237. 
pewne wątpliwości przede wszystkim w kontekście wyraźnego i jednoznacznego określenia zachowania, które penalizuje konkretny przepis. Największe wątpliwości budzi w tym zakresie odesłanie zawarte w art. 115 ust. 3 pr. aut., dlatego poza zakresem rozważań pozostanie stricte cywilna ochrona autorskich dóbr osobistych wynikająca z art. 23 Kodeksu cywilnego ${ }^{3}$. Na marginesie należy wskazać, że o ile na gruncie cywilistycznym dopuszczalna jest pewna niedookreśloność ochrony, o tyle na gruncie norm prawa karnego - zgodnie z zasadą nullum delictum sine lege certa - niedookreśloność taka nie powinna mieć miejsca.

Problem określoności art. 115 ust. 3 pr. aut. był wielokrotnie poruszany w literaturze przedmiotu ${ }^{4}$. Zwracano uwagę, że treść tej normy nie spełnia konstytucyjnych wymogów legislacyjnych odnoszących się do norm karnych, a w szczególności podnoszono, iż norma ta charakteryzuje się nadmierną niedookreślonością ${ }^{5}$. Twierdzenie to miało swoje źródło w wykładni treści art. 42 ust. 1 Konstytucji Rzeczypospolitej Polskiej ${ }^{6}$. W myśl tego przepisu „odpowiedzialności karnej podlega ten tylko, kto dopuścił się czynu zabronionego pod groźbą kary przez ustawę obowiązująca $w$ czasie jego popełnienia. Zasada ta nie stoi na przeszkodzie ukaraniu za czyn, który w czasie jego popełnienia stanowił przestępstwo w myśl prawa międzynarodowego". Niewątpliwie, cytowany przepis Konstytucji RP stanowi wyraz przekonania, że ustawowy nakaz lub zakaz wynikający z przepisów prawa karnego powinien być sformułowany w sposób ścisły i precyzyjny. Jest to zatem wyraz zasady nullum delictum sine lege certa pełniącej funkcję gwarancyjną i służącej ochronie praw jednostek przed nadużyciami organów władzy publicznej.

Na marginesie rozważań wypada zauważyć, że autor niniejszego tekstu podziela obiekcje co do zgodności art. 115 ust. 3 pr. aut. z art. 42 ust. 1 Konstytucji RP. Przepis ten był jednak przedmiotem oceny Trybunału Konstytucyjnego (TK), który wyrokiem z dnia 17 lutego 2015 r. ${ }^{7}$

${ }^{3}$ Ustawa z dnia 23 IV 1964 r. Kodeks cywilny (tekst jedn. DzU. 2017, poz. 459), dalej „k.c.”.

${ }^{4}$ J. Raglewski, Komentarz do art. 115, w: Prawo autorskie i prawa pokrewne. Komentarz, pod red. D. Flisaka, LEX/el. 2015; Z. Ćwiąkalski, Komentarz do art. 115, w: Ustawa o prawie autorskim i prawach pokrewnych. Komentarz, pod red. J. Barty, R. Markiewicza, wyd. 5, LEX el. 2011; R. Markiewicz, S. Soltysiński, Konstytucyjne aspekty praw autorskich (uwagi na marginesie dwóch orzeczeń Trybunału Konstytucyjnego), „Państwo i Prawo” 2015, z. 12, s. 7 i n.

${ }^{5}$ Ibidem.

${ }^{6}$ Konstytucji Rzeczypospolitej Polskiej z dnia 2 IV 1997 r. (Dz.U. Nr 78, poz. 483 ze zm.), dalej „Konstytucja RP”.

${ }^{7}$ Wyrok TK z 17 II 2015 r., sygn. K 15/13, LEX nr 1648132. Z pytaniem o zbadanie konstytucyjności tego przepisu wystąpiła Rzecznik Praw Obywatelskich (RPO) pismem 
orzekł, iż jest on zgodny ze wskazanym przepisem Konstytucji RP. Trybunał stanął na stanowisku, że przepis art. 115 ust. 3 pr. aut. nie jest „pozbawiony zespołu znamion czynu zabronionego i pozwala rozpoznać, jakie zachowania będą podlegać karze, ponieważ znamiona te można zrekonstruować w toku wykładni jako naruszenie cudzych praw autorskich lub praw pokrewnych w celu osiągnięcia korzyści majątkowej. Działanie tego rodzaju, niezależnie od sposobu, podlega penalizacji”. Ponadto TK zauważył, że „dla zaistnienia przestępstwa nie jest istotne, w jaki sposób następuje naruszenie praw autorskich lub praw pokrewnych. Ważne jest, że doszło do naruszenia tych praw i miało to miejsce w celu osiągnięcia korzyści majątkowej"8. Zapatrywanie Trybunału Konstytucyjnego musi zostać uznane za wiążące, jednak budzi ono pewne zastrzeżenia. Oczywiste jest, że zasada określoności ustawy karnej nie wyklucza możliwości posługiwania się przez ustawodawcę zwrotami niedookreślonymi lub ocennymi, jeżeli ich desygnaty da się ustalić ${ }^{9}$. Jednakże art. 115 ust. 3 pr. aut. nie tyle posługuje się zwrotami niedookreślonymi, co zawiera odesłanie do innych przepisów prawa autorskiego, czyniąc przedmiotem przestępstwa naruszenie "autorskich praw osobistych (art. 16), autorskich praw majątkowych (art. 17, art. 18), praw twórcy i jego spadkobierców do wynagrodzenia w wypadku dokonanych zawodowo odsprzedaży oryginalnych egzemplarzy utworu plastycznego lub fotograficznego (art. 19 ust. 1), praw twórcy i jego spadkobierców do wynagrodzenia w wypadku dokonanych zawodowo odsprzedaży rękopisów utworów literackich i muzycznych (art. 1919), praw przysługujących artyście wykonawcy (art. 86), praw przysługujących producentowi fonogramu lub wideogramu (art. 94 ust. 4), praw przysługujących organizacji radiowej lub telewizyjnej (art. 97). Ponadto przedmiotem przestępstwa może być niewykonywanie przez sprzedawcę zajmującego się handlem dziełami sztuki lub rękopisami obowiązku wskazania osoby trzeciej, na rzecz której działa (art. $19^{3}$ ust. 2), nieuiszczanie przez producentów i importerów urządzeń, a także czystych nośników służących do utrwalania utworów lub przedmiotów praw pokrewnych, opłat $\mathrm{z}$ tego tytułu (art. 20 ust. 1-4), nieprzekazywanie przez producentów lub wydawców

z dnia 11 IV 2013 r. (znak: RPO-729135-II-13/ST). W ocenie RPO ustawodawca, wprowadzając określoną w art. 115 ust. 3 pr. aut. odpowiedzialność karna, nie zachował precyzji wymaganej od przepisów regulujących tę formę odpowiedzialności.

${ }^{8}$ Postanowienie TK z 21 V 2009 r., sygn. P 31/07, OTK ZU 2009, nr 9A, poz. 144.

${ }_{9}$ Zob. wyrok TK z 28 I 2003 r., sygn. K 2/02, OTK ZU 2003, nr 1A, poz. 4. 
egzemplarzy utworów, które nie korzystają z ochrony praw autorskich majątkowych, wpłat na Fundusz Promocji Twórczości (art. 40 ust. 1 i 2) ${ }^{\prime \prime 10}$. Ponadto, jak zauważono w uzasadnieniu cytowanego wyroku TK, czynnością wykonawczą opisaną w art. 115 ust. 3 pr. aut. jest czynność „naruszania praw autorskich lub praw pokrewnych” lub „niewykonanie obowiązków".

Ze względu na obszerność problematyki związanej z opisaniem strony podmiotowej i przedmiotowej wszystkich odniesień wymienionych $\mathrm{w}$ art. 115 ust. 3 pr. aut. w niniejszym tekście nacisk położony zostanie na dookreślenie znamion związanych $\mathrm{z}$ naruszeniem art. 16 pr. aut. (autorskie prawa osobiste). Tak zakreślony przedmiot rozważań wymaga postawienia wielu pytań badawczych. W pierwszej kolejności należy się zastanowić nad zakresem czynności czasownikowej w postaci „naruszenia”, jako że w art. 115 ust. 3 pr. aut. jest ona przeciwstawiana innym sposobom dokonania naruszeń aniżeli te, które zostały wskazane w ust. 1 i 2 tego przepisu. Wyłączenie sposobu naruszeń, o których mowa w art. 115 ust. 1 i 2 pr. aut. jako związanych $\mathrm{z}$ autorskimi prawami osobistymi pozwoli odpowiedzieć na pytanie, $\mathrm{w}$ jakim zakresie analizowany przepis karny chroni autorskie prawa osobiste. W konsekwencji sprecyzowanie zakresu ochrony z art. 115 ust. 3 pr. aut. pozwoli na określenie znamion tego przestępstwa. Przed przystąpieniem do dalszych rozważań należy uczynić jedno zastrzeżenie. Omówienie i analiza odnosząca się do art. 16 pr. aut. ograniczona jest zakresem, w jakim treść tego przepisu jest niezbędna do określenia zachowań podlegających penalizacji z art. 115 ust. $3 \mathrm{w}$ zw. z art. 16 pr. aut. Oznacza to, że nie będzie ona obejmowała całości zagadnień, które w świetle art. 16 pr. aut. należałoby poruszyć w aspekcie cywilnoprawnym. Przeprowadzona bowiem w niniejszym tekście interpretacja art. 16 pr. aut. służy określeniu zakresu ochrony karnej, nie zaś cywilnoprawnej.

${ }^{10}$ Wyrok TK z 17 II 2015 r., sygn. K 15/13, LEX nr 1648132. Na marginesie rozważań należy dodać, że Ustawą z dnia 11 IX 2015 r. o zmianie ustawy o prawie autorskim i prawach pokrewnych oraz ustawy o grach hazardowych (Dz.U. 2015, poz. 1639) został uchylony art. 40 pr. aut. Nowelizacja zniosła opłaty na Fundusz Promocji Twórczości pobierane za sprzedaż egzemplarzy utworów, które nie korzystają z ochrony praw autorskich. Fundusz Promocji Twórczości, o którym mowa w przywołanym wyroku TK, został zniesiony i od dnia 1 I 2016 r. zastąpiony Funduszem Promocji Kultury. 


\section{Pojęcie „naruszenia" użyte w art. 115 ust. 3 pr. aut.}

Odnosząc się do pojęcia naruszenia, o którym mowa w art. 115 ust. 3 pr. aut., należy podnieść, że ustawa pr. aut. posługuje się tym pojęciem $\mathrm{w}$ rozumieniu cywilistycznym. Pojęcie to używane jest w ustawie wielokrotnie, jednakże wydaje się, że kluczowym przepisem, który się nim posługuje, jest art. 78 pr. aut. ${ }^{11}$ Regulacja ta jest przepisem odnoszacym się do ochrony autorskich praw osobistych i formułuje roszczenia w przypadku naruszenia właśnie autorskich praw osobistych. W kontekście powyższego nie ulega wątpliwości, że uznanie na gruncie art. 115 ust. 3 pr. aut., iż doszło do naruszenia praw autorskich lub praw pokrewnych, musi być poprzedzone stwierdzeniem, czy sprawca w określonym stanie faktycznym dopuścił się naruszenia przepisów cywilnych pr. aut., do których odsyła wspomniana norma karna. Takie ujęcie może rodzić pewne trudności dla organów prowadzących postępowanie karne, albowiem oznacza to, że stwierdzenie bezprawności w rozumieniu prawa karnego musi być poprzedzone ustaleniem, iż zostało dokonane naruszenie $\mathrm{W}$ rozumieniu prawa autorskiego. $\mathrm{W}$ tym sensie organ procesowy powinien ustalić, że podmiot uprawniony z tytułu prawa autorskiego może skutecznie dochodzić roszczeń wynikających z tytułu naruszenia przepisów, do których odsyła art. 115 ust. 3 pr. aut., tj. czy w ich świetle rzeczywiście doszło do naruszenia. Oznacza to, że w każdym przypadku organ procesowy musi w pierwszej kolejności stwierdzić naruszenie w rozumieniu prawa cywilnego, natomiast samo naruszenie normy karnej może być stwierdzone dopiero wtedy, gdy działanie sprawcy wypełni wszystkie przesłanki umożliwiające skuteczne dochodzenie roszczenia na gruncie prawa cywilnego. Dla przykładu można wskazać, że jedną z form naruszeń, o których mowa w art. 115 ust. 3 pr. aut., może być wkroczenie w integralność utworu (art. 16 pkt 3 pr. aut.). Stwierdzenie, że będą wypełnione znamiona przestępstwa w związku z naruszeniem integralności utworu, w pierwszej kolejności musi być poprzedzone ustaleniem przez organ prowadzący postępowanie, czy rzeczywiście nastąpiła czynność, w związku z którą została naruszona treść lub forma utworu, a następnie w oparciu o normy prawa cywilnego należy zbadać zasadność twierdzenia o naruszeniu. W konsekwencji organ procesowy powinien nie tylko dokonać analizy literalnego brzmienia określonego

\footnotetext{
${ }^{11}$ Innymi przepisami posługującymi się pojęciem „naruszenia” są art. 79 i 80 pr. aut., odnoszące się do autorskich praw majątkowych.
} 
przepisu, do którego odsyła art. 115 ust. 3 pr. aut., lecz także zbadać, czy istnieją na przykład określone normy pr. aut. wyłączające bezprawność określonego działania.

Regulacją uchylającą bezprawność działania w rozumieniu norm prawa cywilnego w związku z wkroczeniem $\mathrm{w}$ integralność utworu jest norma zawarta w art. 49 ust. 2 pr. aut. dająca uprawnienie do czynienia zmian w utworze, jeżeli są one spowodowane oczywistą koniecznością. Szczegółowe rozważania w tym zakresie zostaną przedstawione poniżej, jednakże w kontekście wykładni pojęcia "naruszenie" istotne jest stwierdzenie, że wyłączenie bezprawności w rozumieniu prawa cywilnego wyłączać będzie bezprawność w rozumieniu norm prawa karnego. Prawo karne utożsamia bezprawność ze sprzecznością z normą sankcjonowaną. Owa sprzeczność jest warunkiem koniecznym do uznania bezprawności na gruncie prawa karnego ${ }^{12}$. Nie jest to natomiast warunek wystarczający, gdyż mogą wystąpić okoliczności uprawniające podmiot do określonego działania. Normami uprawniającymi do wkroczenia w cudze prawo autorskie na gruncie pr. aut. mogą być, poza art. 49 ust. 2 pr. aut., także przepisy odnoszące się do dozwolonego użytku publicznego.

Zdecydowanie mniejsze trudności jawią się w zakresie interpretacji pojęcia "niewykonania obowiązków”. Ta czynność czasownikowa odsyła wprost do obowiązków określonych w art. $19^{3}$ ust. 2 pr. aut. oraz art. 20 ust. 1-4 pr. aut. Jak słusznie podniesiono w literaturze przedmiotu, forma sprawcza realizacji znamion czynu zabronionego w tej formie może mieć wyłącznie postać zaniechania ${ }^{13}$. Szczegółowa wykładnia tego pojęcia pozostaje jednak poza zakresem przedmiotowym analizy.

Wydaje się, że sposób, w jaki uczyniono odesłanie w art. 115 ust. 3 pr. aut. do przepisów prawa autorskiego, jest sprzeczny z podstawowymi zasadami techniki legislacyjnej. Zgodnie z Rozporządzeniem Prezesa Rady Ministrów z dnia 20 czerwca 2002 r. w sprawie "Zasad techniki prawodawczej"14, w myśl zasad odnoszących się do sposobu formułowania przepisów karnych, z odesłań można korzystać, gdy „bezprawność czynu polega na naruszeniu nakazów lub zakazów wyraźnie sformułowanych w innych przepisach tej samej ustawy lub w postanowieniach

12 Zob. A. Zoll, Komentarz do art. 1, w: Kodeks karny. Część ogólna, t. 1, cz. 1: Komentarz do art. 1-52, pod red. W. Wróbla, A. Zolla, wyd. 5, Warszawa 2016.

${ }^{13} \mathrm{~J}$. Zagrodnik, Komentarz do art. 115, w: Ustawa o prawie autorskim i prawach pokrewnych. Komentarz, pod red. P. Ślęzaka, Warszawa 2017, Legalis nr 2018.

14 Tekst jedn. Dz.U. 2016, poz. 283, dalej „zasady techniki prawodawczej”. 
umów lub aktów, o których mowa w ust. 1". Ponadto w "takim przypadku w przepisie karnym, stosując odesłanie, używa się zwrotu: "Kto wbrew przepisom art. ... (postanowieniom art. ...)" (§ 75 ust. 2 zasad techniki prawodawczej). Nie ulega wątpliwości, że art. 115 ust. 3 pr. aut. nie spełnia powyższych wymogów legislacyjnych. Skoro jednak został uznany przez Trybunał Konstytucyjny za zgodny z ustawą zasadnicza, należy podjąć próbę sprecyzowania ustawowych znamion podmiotowych i przedmiotowych przestępstwa, którego penalizację przewidziano w art. 115 ust. 3 pr. aut.

Trudność w precyzyjnym określeniu znamion strony przedmiotowej tego przestępstwa polega na tym, że przepisy, do których odsyła art. 115 ust. 3 pr. aut., nie formułują nakazów lub zakazów, lecz są przepisami określającymi prawa podmiotów uprawnionych z tytułu praw autorskich lub praw pokrewnych. Nie ulega przy tym wątpliwości, że normy prawa karnego powinny być formułowane w sposób jasny i zrozumiały dla każdego obywatela.

Ze względu na stanowisko zajęte przez Trybunał Konstytucyjny należy postawić pytanie, jakie są znamiona strony przedmiotowej i strony podmiotowej tego przestępstwa w kontekście art. 16 pr. aut. Podjęcie powyższych rozważań należy rozpocząć od określenia strony podmiotowej, albowiem w odróżnieniu od strony przedmiotowej będzie ona wspólna dla wszystkich naruszeń związanych z przepisami, do których odsyła art. 115 ust. 3 pr. aut.

\section{Strona podmiotowa przestępstwa $z$ art. 115 ust. 3 pr. aut.}

W pierwszej kolejności trzeba zauważyć, że zamiar sprawcy należy ustalić na podstawie całokształtu zarówno przedmiotowych, jak i podmiotowych okoliczności, a wyjaśnienia oskarżonego nie mogą stanowić jedynej, a nawet głównej okoliczności w zakresie ustaleń co do zamiaru. Ponadto przy "zamiarze bezpośrednim niezbędna jest świadomość sprawcy co do celu i środków do tego prowadzących, czyli znamion czynu zabronionego oraz wola ich realizacji"15.

Odnosząc się do strony podmiotowej przestępstwa stypizowanego $\mathrm{w}$ art. 115 ust. 3 pr. aut., należy zwrócić uwagę, że jest to przestępstwo

${ }^{15}$ Postanowienie Sądu Najwyższego (SN) z 20 IV 2017 r., sygn. II KK 104/17, LEX nr 2281245. 
umyślne, zaliczane do tzw. odmiany celowościowej przestępstw kierunkowych. Wspomniany zamiar kierunkowy (dolus coloratus) jest immanentnym elementem strony podmiotowej takich przestępstw ${ }^{16}$. Ustawa wymaga zatem, aby zachowanie sprawcy było ukierunkowane na określony cel, którym w przypadku przestępstwa z art. 115 ust. 3 pr. aut. jest osiągnięcie korzyści majątkowej. Sprawca, podejmując działanie, musi mieć wyobrażenie pożądanej dla niego sytuacji, która stanowić ma rezultat jego zachowania. Oznacza to, że takie ujęcie znamion strony podmiotowej wyklucza możliwość popełnienia tego przestępstwa z zamiarem ewentualnym. W konsekwencji zamiar bezpośredni winien obejmować zarówno cel, jak i sam sposób działania zmierzający do zrealizowania tego celu ${ }^{17}$.

W orzecznictwie sądowym przyjmuje się, że pojęcie korzyści majątkowej jest niezwykle szerokie. Wprawdzie zgodnie z art. $115 \S 4$ Ustawy z dnia 6 czerwca 1997 r. - Kodeks karny ${ }^{18}$ "korzyścią majątkową lub osobistą jest korzyść zarówno dla siebie, jak i dla kogo innego", to w judykaturze uznaje się, że jest to pojęcie wykraczające "znacznie poza zakres przywłaszczenia cudzego mienia i wiąże się z jakąkolwiek poprawą sytuacji majątkowej (materialnej) sprawcy lub innej osoby, przejawiają się nawet w postaci choćby krótkotrwałego, ale bezprawnego korzystania z cudzego mienia"19. Ponieważ Kodeks karny nie definiuje pojęcia mienia, w tym zakresie należy odwołać się do regulacji określonej w art. 44 k.c. Definiuje on mienie jako własność i inne prawa majątkowe. Należy jednak pamiętać, że z punktu widzenia regulacji prawa autorskiego nie wszystkie odesłania z art. 115 ust. 3 pr. aut. odnoszą się do autorskich praw majątkowych. Omawiane odesłanie do art. 16 pr. aut. odnosi się do autorskich praw osobistych, a nie praw majątkowych. $Z$ tego względu pojęcie korzyści majątkowej, o którym mowa w art. 115 ust. 4 k.k., należy oderwać od pojęcia mienia. Znaczenie korzyści majątkowej w rozumieniu tego przepisu należy utożsamić bądź z takim działaniem sprawcy, które zwiększy stan jego aktywów, bądź takim, które będzie polegać na zmniejszeniu jego pasywów.

${ }^{16}$ Zob. M. Budyn-Kulik, Komentarz do art. 9, w: Kodeks karny. Komentarz aktualizowany, pod red. M. Mozgawy, LEX nr 2017.

17 Wyrok Sądu Apelacyjnego (SA) w Warszawie z 14 XIII 2016 r., sygn. II AKa 372/16, LEX nr 2191544.

18 Tekst jedn. Dz.U. 2017, poz. 2204, dalej „k.k.”.

${ }^{19}$ Wyrok SA w Gdańsku z 26 III 2015 r., sygn. II AKa 456/14, LEX nr 1953161. 


\section{Strona przedmiotowa przestępstwa związana z naruszeniem autorskich praw osobistych $\mathrm{z}$ art. 115 ust. 3 pr. aut.}

O ile strona podmiotowa przestępstwa $\mathrm{z}$ art. 115 ust. 3 pr. aut. została opisana w sposób jasny i niebudzący wątpliwości, o tyle odniesienie się do zagadnień związanych ze stroną przedmiotową będzie wymagało głębszej analizy. Z tego punktu widzenia prawidłowa wykładnia strony przedmiotowej tego przestępstwa wymaga rozważenia każdego z odniesień w nim zawartych. W pierwszej jednak kolejności należy poczynić pewne ogólne uwagi dotyczące sposobu popełnienia przestępstwa $z$ art. 115 ust. 3 pr. aut. Jak już wspomniano, zgodnie z tą regulacją penalizowane jest:

a. naruszenie cudzych praw autorskich lub praw pokrewnych określonych $\mathrm{w}$ art. 16, art. 17, art. 18, art. 19 ust. 1, art. 191, art. 86, art. 94 ust. 4 lub art. 97 pr. aut. w sposób inny niż określony w art. 115 ust. 1 i 2 pr. aut. oraz

b. niewykonanie obowiązków określonych w art. $19^{3}$ ust. 2 lub art. 20 ust. 1-4 pr. aut.

Ze względu na przedmiot rozważań istotne jest wyłącznie odesłanie do art. 16 pr. aut. W kontekście powyższego oznacza to, że czynnością czasownikową wspomnianego przestępstwa jest "dokonanie naruszenia" związanego z autorskimi prawami osobistymi. Ponadto w kontekście czynności naruszenia należy wyłączyć te formy sprawstwa, które opisane są w art. 115 ust. 1 i 2 pr. aut. jako związane z autorskimi prawami osobistymi. Nie ulega wątpliwości, że art. 115 ust. 1 pr. aut., odnosząc się do przywłaszczenia autorstwa bądź wprowadzenia w błąd co do autorstwa całości lub części cudzego utworu albo artystycznego wykonania, wskazuje, że zakresem ochrony objęte są prawa osobiste, tj. autorskie prawo osobiste w postaci autorstwa utworu (art. 16 pkt 1 pr. aut.) oraz tak samo rozumiane dobro osobiste artysty wykonawcy ${ }^{20}$.

W efekcie, w kontekście powyższego, należy postawić tezę, że w zakresie, w jakim art. 115 ust. 1 pr. aut. penalizuje działania wkraczające $\mathrm{w}$ autorskie prawo osobiste $\mathrm{w}$ postaci prawa do autorstwa utworu (art. 16 ust. 1 pr. aut.), takie działania nie są objęte naruszeniem autorskich praw osobistych, o których mowa w ust. 3 art. 115 pr. aut. w zakresie, w jakim przepis odsyła do art. 16 pr. aut. Podobne wnioski

${ }^{20}$ Na marginesie rozważań należy zwrócić uwagę, że art. 86 ust. 1 pkt 1 pr. aut. co prawda formułuje otwarty katalog dóbr osobistych artysty wykonawcy, jednak przepis ten nie ma swojego odpowiednika w postaci art. 16 ust. 1 pr. aut. (autorstwo utworu). 
należy wyciągnąć z analizy art. 115 ust. 2 w zw. z art. 115 ust. 3 pr. aut. Zakresem penalizacji opisanej w ust. 2 jest mianowicie objęte działanie tego, „kto rozpowszechnia bez podania nazwiska lub pseudonimu twórcy cudzy utwór w wersji oryginalnej albo w postaci opracowania, artystyczne wykonanie albo publicznie zniekształca taki utwór, artystyczne wykonanie, fonogram, wideogram lub nadanie". Nie ulega wątpliwości, że art. 115 ust. 2 pr. aut. chroni autorskie prawo osobiste opisane $w$ art. 16 pkt 2 pr. aut., jednakże z jednym zastrzeżeniem. Wspomniany przepis art. 115 ust. 2 pr. aut. nie odnosi się do sytuacji, gdy twórca wyraził wolę udostępnienia utworu anonimowo. Jeśli taką wolę wyraził, utwór zaś zostanie rozpowszechniony przez określony podmiot wraz z powołaniem się na nazwisko lub pseudonim twórcy, takie zachowanie niewątpliwie narusza prawo twórcy z art. 16 ust. 2 pr. aut. W konsekwencji takiego sposobu rozpowszechniania utworu czyn taki może być zakwalifikowany jako wypełniający znamiona z art. 115 ust. 3 pr. aut. Poza poczynionymi wyżej uwagami wszystkie pozostałe formy wkroczenia $\mathrm{w}$ autorskie prawa osobiste $\mathrm{w}$ postaci rozpowszechnienia utworu bez podania nazwiska lub pseudonimu twórcy będą wyłączone spod penalizacji art. 115 ust. 3 pr. aut. Należy także zwrócić uwagę, że zarówno przepisy oddziału 4. „Postanowienia wspólne dotyczące praw pokrewnych", jak i art. 92 pr. aut. dotyczącego artystycznych wykonań nie odsyłają do odpowiedniego stosowania art. 16 pr. aut. odnoszącego się do autorskich praw osobistych. Oznacza to, że odesłanie do art. 16 pr. aut., o którym mowa w art. 115 ust. 3 pr. aut., należy odnieść wyłącznie do naruszenia praw osobistych twórcy.

Wypada zwrócić uwagę, że o ile podmiotem, który może dopuścić się naruszenia art. 16 pr. aut., może być każdy, to pokrzywdzonym może być wyłącznie twórca, albowiem autorskie prawa osobiste nie podlegaja zrzeczeniu się lub zbyciu. W kontekście powyższego należy zastanowić się, jaki katalog zachowań w postaci naruszeń będzie podlegać penalizacji ze względu na naruszenie autorskich praw osobistych, o których mowa w przywołanym w poprzednim zdaniu przepisie. Odpowiedź na to pytanie wydaje się niejednoznaczna, gdyż art. 16 pr. aut. formułuje otwarty katalog autorskich praw osobistych, definiując te prawa jako "więź twórcy z utworem". Z punktu widzenia regulacji prawnokarnej trudno uznać działanie w postaci "naruszenia więzi twórcy z utworem” za znamię czyniące zadość zasadzie określoności czynu zabronionego, o którym mowa w art. 42 ust. 1 Konstytucji RP. Należy się więc 
zastanowić, jakie konkretne zachowania można uznać za naruszające art. 16 pr. aut. w rozumieniu art. 115 ust. 3 pr. aut.

Autor stoi na stanowisku, że jedynymi możliwymi zachowaniami, które mogłyby podlegać penalizacji w rozumieniu art. 115 ust. 3 pr. aut., są zachowania wkraczające $\mathrm{w}$ autorskie prawa osobiste, o których mowa w art. 16 pkt 3-5 pr. aut. Tylko te autorskie prawa osobiste twórcy mogą bowiem być uznane za sprecyzowane na tyle, że możliwe jest zdekodowanie zespołu zachowań czyniących zadość zasadzie określoności czynu zabronionego.

\subsection{Naruszenie prawa do integralności utworu oraz jego rzetelnego wykorzystania}

Precyzując zachowania naruszające art. 16 pkt 3 pr. aut., należy odwołać się do orzecznictwa sądowego. Zgodnie z wyrokiem Sądu Najwyższego z dnia 21 marca 2014 r. "do naruszenia prawa do integralności utworu (art. 16 pkt 3 pr. aut.) dochodzi wówczas, gdy zostaje naruszona więź pomiędzy twórcą a utworem wskutek dokonania przez sprawcę naruszenia zmian utworu, pominięcia jego części, wprowadzenia dodatków lub uzupełnień, zmiany utworów muzycznych stanowiących część widowiska muzyczno-tanecznego albo gdy następuje jego nierzetelne, niedbałe wykonanie. Oznacza to, że nie każda zmiana stanowi naruszenie i dozwolone są drobne zmiany treści lub formy zmiany odnoszące się do elementów utworu, nienaruszające wspomnianej więzi"21. Z przytoczonego poglądu SN wynika bezpośrednio, że nie wszystkie zmiany czynione w utworze będą prowadziły do naruszenia autorskiego prawa osobistego. Na pewno nie będą stanowiły naruszenia drobne zmiany nienaruszające więzi twórcy z utworem. W kontekście powyższego należy zwrócić uwagę, że co prawda sama "więź twórcy z utworem" nie może być uznana za przesłankę penalizująca, to jednak trzeba pamiętać, iż opisane w art. 16 ust. 3 pr. aut. prawo do integralności utworu jest skonkretyzowaniem (określeniem) tego autorskiego prawa osobistego. Oznacza to, że skoro prawo do integralności utworu jest jedną z form "więzi twórcy z utworem”, to stwierdzenie, iż wkroczenie w integralność jest na tyle znikome, że nie powoduje naruszenia tej więzi, musi prowadzić do wniosku, iż takie działanie nie będzie czynem zabronionym w rozumieniu art. 115 ust. 3 pr. aut.

${ }^{21}$ Wyrok SN z 21 III 2014 r., sygn. IV CSK 407/13, OSNC 2015, nr 3, poz. 36. 
Odnosząc się do innych okoliczności, które wyłączają odpowiedzialność karną za naruszenie art. 16 pkt 3 pr. aut., należy zwrócić uwagę, że w stosunkach umownych przyjęte jest rozwiązanie, iż twórca może zobowiązać się do niewykonywania swoich autorskich praw osobistych lub zezwolić innej osobie na wykonywanie tych praw w jego imieniu. Zdaniem doktryny w takim przypadku dochodzi do wykonywania autorskich praw osobistych, a nie do ich zrzeczenia się 22 . Przyjęcie takiego rozwiązania przez strony kontraktu stanowi niewątpliwie okoliczność wyłączającą odpowiedzialność karną podmiotu wkraczającego w autorskie prawa osobiste. Nie można bowiem postawić zarzutu, że wkroczenie to nastąpiło $\mathrm{w}$ sposób bezprawny, jeśli podmiot uprawniony z tytułu autorskich praw osobistych godzi się na takie wkroczenie. Na marginesie rozważań należy wskazać, że powyższe uwagi dotyczące rozwiązań kontraktowych odnoszą się także do innych naruszeń stypizowanych w art. 16 pkt 4 i 5 pr. aut.

Kolejną okolicznością wyłączającą odpowiedzialność karną jest ta, o której mowa w art. 49 ust. 2 pr. aut. Zgodnie z tym przepisem "następca prawny, choćby nabył całość autorskich praw majątkowych, nie może, bez zgody twórcy, czynić zmian w utworze, chyba że są one spowodowane oczywistą koniecznością, a twórca nie miałby słusznej podstawy im się sprzeciwić". Zgodnie natomiast z poglądem wyrażonym w doktrynie "konieczność zmiany jest oczywista, kiedy każdy, kto miałby korzystać z utworu i oceniał sprawy rozsądnie ( $z$ uwzględnieniem oczywiście specyfiki branży, szczególnej wiedzy itp.), uznałby, że zmiana musi zostać wprowadzona" ${ }^{23}$. Słuszna podstawa sprzeciwu „oznacza zatem w istocie godne ochrony, przeważające nad interesami nabywcy praw, interesy twórcy" ${ }^{\prime \prime 2}$. W konsekwencji przyjmuje się, że mogą to być wyłącznie interesy o charakterze osobistym. Problematyczne pozostaje, jak należy rozumieć okoliczność wyłączającą odpowiedzialność z art. 49 ust. 2 pr. aut. na gruncie regulacji prawa karnego, albowiem przyjmuje się, że to podmiot uprawniony $\mathrm{z}$ tytułu autorskich praw osobistych powinien wykazać, iż posiada słuszną podstawę sprzeciwu ${ }^{25}$.

${ }^{22}$ J. Barta, R. Markiewicz, Komentarz do art. 16, w: Ustawa o prawie autorskim i prawach pokrewnych. Komentarz, pod red. J. Barty, R. Markiewicza, wyd. 5, LEX 2011.

${ }^{23}$ T. Targosz, Komentarz do art. 49, w: Prawo autorskie i prawa pokrewne. Komentarz, pod red. D. Flisaka, LEX 2015.

${ }^{24}$ Ibidem.

${ }^{25}$ Ibidem. 
W realiach procesu karnego oznacza to, że wystarczy, iż podmiot naruszający powoła się na fakt "konieczności zmiany" w rozumieniu art. 49 ust. 2 pr. aut. Korzystając z tej instytucji wyłączającej odpowiedzialność karną, nie musi powoływać się na żadne inne okoliczności. To w gestii organu prowadzącego postępowanie karne pozostaje ewentualne ustalenie, że była słuszna podstawa do sprzeciwienia się dokonaniu określonych zmian, które naruszały więź twórcy z utworem.

Odnosząc się natomiast do zakresu prawa do rzetelnego wykorzystania utworu, należy wskazać, że w judykaturze opowiedziano się za "szerokim rozumieniem zwrotu „rzetelne wykorzystanie utworu”. W jednym z orzeczeń Sąd Najwyższy uznał, iż wobec braku jego definicji legalnej należy uznać za wskazane sięgnięcie do kryteriów określonych w art. 49 ust. 1 pr. aut. Przepis ten ma charakter klauzuli generalnej, zastępującej dyspozycje stron umowy i zezwalającej na odtworzenie zakresu uprawnień korzystającego z utworu. Zgodnie z tym uregulowaniem sposób korzystania z utworu powinien być zgodny z charakterem i przeznaczeniem utworu oraz przyjętymi zwyczajami ${ }^{26}$. W literaturze przedmiotu podnoszono, że naruszenie prawa do rzetelnego wykorzystania utworu w praktyce często ma miejsce bez dokonania ingerencji w utwór i może obejmować np.: (1) niewłaściwą prezentację (udostępnienie) utworu publiczności, naruszającą więź twórcy z utworem, (2) wykorzystanie dzieła w sposób wprowadzający w błąd co do charakteru i podstawowych, przyjętych w nim kryteriów wartości, (3) tendencyjny wybór cytatów, wywołujący błędne wyobrażenie o utworze ${ }^{27}$. Odnosząc się natomiast do problematyki tendencyjnego wykorzystania cytatu, należy zauważyć, że w literaturze przedmiotu wskazano, iż świadomie tendencyjny wybór to taki, który wywołuje u publiczności fałszywe wyobrażenie o utworze, co w konsekwencji nie prowadzi do naruszenia prawa cytatu (art. 29 pr. aut), lecz pozostaje w sprzeczności z prawem twórcy do rzetelnego wykorzystania utworu ${ }^{28}$. W konsekwencji należy stwierdzić, że wyżej wymienione zachowania mogą stanowić podstawę ewentualnej odpowiedzialności karnej, o której mowa w art. 115 ust. 3 w zw. z art. 16 pr. aut.

${ }^{26}$ Wyrok SN 6 XII 2013 r., sygn. I CSK 109/13, LEX nr 1444325.

${ }_{27}$ Zob. E. Wojnicka, B. Giesen, w: System prawa prywatnego, t. 13: Prawo autorskie, pod red. J. Barty, Warszawa 2013, s. 346-347; E. Wojnicka, Ochrona autorskich dóbr osobistych, Łódź 1997, s. 194.

${ }^{28}$ Por. A.M. Niżankowska, Prawo do integralności utworu, Warszawa 2007, s. 160 i n. 


\subsection{Naruszenie prawa do decydowania o pierwszym udostępnieniu utworu}

Kolejną kwestią jest forma naruszenia, określona w art. 16 pkt 4 pr. aut., tj. wyłączność twórcy o decydowaniu o pierwszym udostępnieniu utworu publiczności. Zdaniem J. Barty i R. Markiewicza przez pojęcie udostępnienia utworu publiczności należy rozumieć "opublikowanie (art. 6 ust. 1 pkt 1) lub inne rozpowszechnienie utworu (art. 6 ust. 1 pkt 3), które stwarza możliwość zapoznania się z dziełem nieograniczonej z góry liczbie osób" ${ }^{\prime 29}$. W kontekście przytoczonego powyżej poglądu prawidłowa wykładnia art. 115 ust. 3 pr. aut. polegającego na naruszeniu art. 16 pkt 4 pr. aut. wymaga uwzględnienia zakresu penalizacji z art. 116 ust. 1 pr. aut., który odnosi się do nieuprawnionego rozpowszechniania utworu. Zgodnie z art. 116 ust. 1 pr. aut. karze podlega ten, „kto bez uprawnienia albo wbrew jego warunkom rozpowszechnia cudzy utwór $\mathrm{w}$ wersji oryginalnej albo w postaci opracowania, artystyczne wykonanie, fonogram, wideogram lub nadanie". W zakresie penalizacji na podstawie art. 116 pr. aut. pozostaje czynność polegająca na rozpowszechnieniu utworu bez uprawnienia lub wbrew jego warunkom. Oznacza to, że penalizacji w rozumieniu art. 116 ust. 1 pr. aut. będą podlegały tylko takie publiczne udostępnienia, które zostały poprzedzone pierwszym zezwoleniem twórcy na publiczne udostępnienie. Taka interpretacja wynika $z$ definicji utworu rozpowszechnionego $w$ rozumieniu art. 6 ust. 1 pkt 3 pr. aut. Zgodnie z tym przepisem „utworem rozpowszechnionym jest utwór, który za zezwoleniem twórcy został w jakikolwiek sposób udostępniony publicznie". A contrario oznacza to, że w zakresie penalizacji objętej art. 115 ust. 3 pr. aut. pozostają wyłącznie takie publiczne udostępnienia utworów, które nie zostały poprzedzone decyzją twórcy o pierwszym ich udostępnieniu publiczności. Taka interpretacja wydaje się uzasadniona, ponieważ art. 116 ust. 1 pr. aut. nie może penalizować tych samych zachowań, które objęte są art. 115 ust. 3 w zw. z art. 16 pkt 4 pr. aut. Ponadto zgodnie z orzecznictwem Sądu Apelacyjnego w Warszawie "decyzja o udostępnieniu utworu - jako uprawnienie osobiste twórcy - ma charakter jednoznaczny. Z momentem zrealizowania przez twórcę tego uprawnienia dalsze wykorzystanie utworu jest kwestią wykonania uprawnień o charakterze majątkowym"30. Oznacza to, że

\footnotetext{
${ }^{29}$ J. Barta, R. Markiewicz, op. cit.

${ }^{30}$ Wyrok SA w Warszawie z 28 IV 1994 r., sygn. I ACr 251/94, LEX nr 62594.
} 
zakresem penalizacji art. 115 ust. $3 \mathrm{w}$ zw. $\mathrm{z}$ art. 16 pkt 4 pr. aut. objęte jest wkroczenie sprawcy $w$ autorskie prawa osobiste, penalizacja opisana w art. 116 ust. 1 pr. aut. obejmuje zaś wkroczenie sprawcy w autorskie prawa majątkowe. Na marginesie rozważań należy pozostawić fakt, że w sytuacji, w której utwór został udostępniony publicznie bez decyzji twórcy, sprawca podlega karze grzywny, ograniczenia wolności albo pozbawienia wolności do roku. Natomiast w sytuacji, gdy utwór został rozpowszechniony bez uprawnienia lub wbrew warunkom uprawnienia (a więc poprzedzony zgodą twórcy na udostępnienie publiczności), sprawca będzie podlegał grzywnie, karze ograniczenia wolności albo pozbawienia wolności do lat 2 . Taki zabieg wydaje się niezrozumiały.

\subsection{Naruszenie prawa do nadzoru nad sposobem korzystania $z$ utworu}

Odnosząc się do ostatniego z możliwych naruszeń związanych z art. 16 pr. aut., tj. dotyczącego prawa autora do nadzoru nad sposobem korzystania z utworu (pkt 5 przywołanego przepisu), należy w pierwszej kolejności zwrócić uwagę, że samo prawo do nadzoru nie zostało zdefiniowane $\mathrm{w}$ tym przepisie. Ze względu na to, iż prawo karne zgodnie z zasadą określoności powinno w sposób precyzyjny określać przesłanki odpowiedzialności karnej, należy uznać, że z naruszeniem art. 16 pkt 5 pr. aut. w kontekście art. 115 ust. 3 pr. aut. będziemy mieli do czynienia wyłącznie w sytuacji, gdy prawo sprawowania nadzoru autorskiego będzie wynikać z innych przepisów pr. aut. To właśnie te przepisy będą dookreślały treść prawa do sprawowania nadzoru autorskiego i w konsekwencji wskazywały, kiedy konkretnie z takiego prawa autor może skorzystać. Powyższa teza odnosi się wyłącznie do zakresu ochrony prawnokarnej i nie oznacza, że prawo nadzoru nad sposobem korzystania $\mathrm{z}$ utworu $\mathrm{w}$ zakresie ochrony prawa cywilnego realizuje się wyłącznie w sytuacji, gdy prawo to wynika wprost z innych przepisów pr. aut.

Normą kluczową opisującą zakres sprawowania nadzoru autorskiego przez twórcę jest regulacja przyjęta w art. 60 ust. 1 pr. aut. Zgodnie z tym przepisem "korzystający z utworu jest obowiązany umożliwić twórcy przed rozpowszechnieniem utworu przeprowadzenie nadzoru autorskiego. Jeżeli wniesione w związku z nadzorem zmiany w utworze są niezbędne i wynikają z okoliczności od twórcy niezależnych, koszty 
ich wprowadzenia obciążają nabywcę autorskich praw majątkowych lub licencjobiorcę". Na tle powyższego przepisu należy poczynić kilka uwag.

Przede wszystkim wypada zauważyć, że ma on zastosowanie wyłącznie w sytuacji, kiedy twórca zawarł umowę o korzystanie z utworu. Oznacza to, że konstruując zarzut odnoszący się do naruszenia art. 115 ust. 3 pr. aut. w zw. z art. 16 pkt 5 pr. aut., w pierwszej kolejności organ procesowy powinien ustalić, czy pomiędzy twórcą a naruszycielem zawarta została umowa. Dopiero spełnienie tego warunku pozwoli na ustalenie, czy faktycznie podmiot naruszający uniemożliwił przeprowadzenie twórcy nadzoru autorskiego. Należy dodać, że podmiot korzystający z utworu może wyznaczyć twórcy odpowiedni termin na wykonanie swojego prawa nadzoru autorskiego (art. 60 ust. 2 pr. aut.). W przypadku nieskorzystania $\mathrm{z}$ tego prawa w wyznaczonym terminie ustawa traktuje taką sytuację jako wyrażenie zgody na rozpowszechnianie utworu. Rozważając moment, w którym autor może skorzystać z prawa nadzoru, należy zauważyć, że prawo określone w art. 60 ust. 1 pr. aut. może zostać wykonane wyłącznie w stosunku do utworu, który nie został jeszcze rozpowszechniony, tj. takiego, który za zezwoleniem twórcy nie został w jakikolwiek sposób udostępniony publicznie (art. 6 ust. 1 pkt 3 pr. aut.) $)^{31}$. Oznacza to, że jeżeli utwór będzie utworem rozpowszechnionym w rozumieniu art. 6 ust. 1 pkt 3 pr. aut., autorowi nie będzie już przysługiwało prawo do nadzoru. W tym sensie trzeba postawić tezę, iż zezwolenie twórcy na publiczne udostępnienie utworu wyczerpuje jego prawo do sprawowania nadzoru autorskiego w rozumieniu art. 60 ust. 1 pr. aut.

Na marginesie rozważań należy zauważyć, że nadzór ma z jednej strony „zapobiegać i usuwać błędy i usterki”, a z drugiej - że jego celem jest "stworzenie twórcy możliwości przeprowadzenia zmian $\mathrm{w}$ utworze ${ }^{\prime \prime 32}$. Ponadto $\mathrm{w}$ literaturze przedmiotu zwrócono uwagę, iż prawo do skorzystania z art. 60 pr. aut. przysługuje w szczególności w przypadku dokonywania zmian w utworze, które mają charakter twórczy ${ }^{33}$.

${ }^{31}$ Na marginesie należy zwrócić uwagę, że w stosunku do utworu audiowizualnego podmiotem zobowiązanym do umożliwienia wykonania nadzoru autorskiego będzie jego producent, natomiast zgodnie z art. 73 pr. aut. „prawo do nadzoru autorskiego może być wykonywane tylko w stosunku do ostatecznej wersji utworu audiowizualnego".

32 Zob. M. Kępiński, Umowy prawa autorskiego, w: System Prawa Prywatnego. Prawo autorskie, t. 13, pod red. J. Barty, Warszawa 2013, s. 628.

${ }^{33}$ Zob. T. Targosz, op. cit. 
W zakresie prawa do przeprowadzenia nadzoru szczególne regulacje przewidziano dla utworów architektonicznych i architektoniczno-urbanistycznych, albowiem w myśl art. 60 ust. 5 pr. aut. sprawowanie nadzoru autorskiego nad utworami architektonicznymi i architektoniczno-urbanistycznymi regulują odrębne przepisy. W przekonaniu autora oznacza to, że art. 16 ust. 5 pr. aut. jest normą o charakterze ogólnym, która przyznaje twórcy utworu architektonicznego uprawnienie do sprawowania nadzoru autorskiego, jednak wyłącznie w zakresie, w jakim regulują to odrębne przepisy. Taka wykładnia wynika z literalnego brzmienia art. 60 ust. 5 pr. aut., który odsyła do odrębnych przepisów. W obecnie obowiązującym stanie prawnym jedynymi przepisami, które regulują sprawowanie nadzoru nad utworem architektonicznym, są przepisy Ustawy z dnia 7 lipca 1994 r. - Prawo budowlane ${ }^{34}$. Stwierdzić zatem trzeba, że do nadzoru autorskiego nad utworem architektonicznym stosować należy przepisy Prawa budowlanego ze wszystkimi tego konsekwencjami. Na marginesie rozważań istotna jest uwaga, że ustawa Prawo budowlane nie wskazuje autora projektu jako podmiotu, który wykonuje nadzór autorski, natomiast posługuje się pojęciem projektanta. Zgodnie zaś z art. 17 pkt 3 pr. bud. projektant jest uczestnikiem procesu budowlanego. Ponadto zgodnie z orzecznictwem "projektantem w rozumieniu art. 17 pr. bud. nie jest autor tego projektu, ale projektant, który zindywidualizował projekt, dostosowując go do konkretnej inwestycji. W tym rozumieniu projektantem będzie zawsze osoba, która podpisała projekt, zatwierdzony następnie przez właściwy organ architektoniczno-budowlany"35. W konsekwencji należy uznać, że autorzy projektów architektonicznych lub architektoniczno-urbanistycznych nie będą objęci ochroną prawnokarną określoną art. 115 ust. 3 w zw. z art. 16 pkt 5 pr. aut. w zakresie sprawowania nadzoru autorskiego, o którym mowa w art. 60 pr. aut. ${ }^{36}$

W literaturze przedmiotu wyrażono pogląd, że poszczególne uprawnienia objęte nadzorem nad korzystaniem z utworu zostały ponadto

\footnotetext{
${ }^{34}$ Tekst jedn. Dz.U. 2017, poz. 1332 ze zm., dalej „pr. bud.”.

${ }^{35}$ Wyrok Wojewódzkiego Sądu Administracyjnego w Lublinie z 13 III 2014 r., sygn. II SA/Lu 24/14, LEX nr 1522608.

${ }^{36} \mathrm{~W}$ jednym ze swoich wyroków Krajowa Izba Odwoławcza (KIO) stwierdziła, że przepisy ustawy Prawo budowlane ograniczają "nadzór autorski do sprawowania nadzoru nad robotami budowlanymi, w zakresie zgodności realizacji z projektem oraz uzgadniania możliwości wprowadzenia rozwiązań zamiennych w stosunku do przewidzianych w projekcie. Powyższe uzasadnia zatem twierdzenie, iż inwestor może również powierzyć nadzór innemu projektantowi" (zob. wyrok KIO z 24 I 2012 r., sygn. KIO 90/12, LEX nr 1110260).
} 
unormowane w art. 56 i 58 pr. aut. ${ }^{37}$ Jednakże ze względu na zbyt ogólne sformułowanie tych norm, należy uznać, że nie czynią one zadość zasadzie określoności. Tym samym ich dyspozycje nie mogą być uznane za zachowania mogące stanowić o odpowiedzialności karnej sprawcy ${ }^{38}$.

Ponadto istotna jest jeszcze jedna uwaga ogólna. Zgodnie $\mathrm{z}$ art. 77 pr. aut. do programów komputerowych nie stosuje się art. 16 pkt 3-5 pr. aut., co oznacza, że penalizacji z art. 115 ust. 3 pr. aut. nie będzie podlegało wkroczenie $w$ autorskie prawa osobiste twórcy związane z prawem do integralności utworu, decydowania o pierwszym udostępnieniu utworu publiczności, jak i nadzorem nad sposobem korzystania z utworu.

\section{Podsumowanie}

Jak wynika z przeprowadzonych rozważań, precyzyjne określenie zakresu penalizacji przewidzianego w art. 115 ust. 3 pr. aut. w związku z naruszenie autorskich praw osobistych jest materią zawiłą i wymagającą szczegółowej analizy przepisów ustawy pr. aut. W kontekście powyższego uzasadniony wydaje się pogląd, że trudno każdego obywatela zobowiązać, aby w sposób dogłębny analizował przepisy pr. aut. na płaszczyźnie prawa karnego oraz cywilnego. W sprawach z zakresu naruszeń art. 115 ust. 3 pr. aut. należałoby rozważyć, czy w konkretnym przypadku nie mamy do czynienia z błędem co do prawa, o którym mowa w art. 33 k.k. Zgodnie z poglądem wyrażonym w orzecznictwie „z błędem co do prawa mamy do czynienia wówczas, gdy sprawca, mając świadomość realizacji określonego czynu, ma jednak mylny obraz prawnego wartościowania swojego zachowania (jest to tzw. błąd pierwotny). Sprawca nie musi przy tym myśleć «słowami ustawy», internalizując jej werbalną treść. Wystarczającym jest, że zdaje sobie ogólnie sprawę, że to, co robi, jest przez prawo zabronione" ${ }^{\prime 39}$.

${ }^{37}$ Zob. J. Barta, R. Markiewicz, op. cit.

${ }^{38}$ Jak podniesiono w literaturze przedmiotu, wprawdzie „w treści przepisów art. 56 i 58 pr. aut. nie posłużono się terminem «nadzór», to jednak uprawnienia przewidziane dla twórcy związane są z kontrolą sposobu wykorzystywania utworu, tj. z nadzorem nad sposobem korzystania $z$ utworu na podstawie umowy ( $z$ uwzględnieniem istotnych interesów twórczych - art. 56 lub z uwzględnieniem formy udostępnienia utworu, wprowadzonych zmian - art. 58)" (zob. S. Stanisławska-Kloc, Komentarz do art. 16, w: Prawo autorskie i prawa pokrewne. Komentarz, pod red. D. Flisaka, LEX 2015).

${ }^{39}$ Zob. wyrok SA w Warszawie z 6 III 2017 r., sygn. II AKa 10/17, LEX nr 2249953. Ponadto zgodnie z orzecznictwem SN „przedmiotem świadomości sprawcy nie ma być 
Na marginesie należy zauważyć, iż zgodnie z orzecznictwem Europejskiego Trybunału Praw Człowieka (ETPC) „czyny zagrożone karą i odpowiadające im kary muszą być wyraźnie określone przez prawo. Wymóg ten zostaje spełniony wówczas, gdy jednostka może wywieść z brzmienia odnośnego przepisu - oraz, gdy zachodzi taka potrzeba, przy pomocy sądowej interpretacji tego przepisu - jakie działania lub zaniechania sprawia, że poniesie ona odpowiedzialność karną" ${ }^{\prime \prime}$. Z orzecznictwa ETPC wynika, iż ustawa musi spełniać wymóg „przewidywalności". Wymóg ten jest stawiany nawet tam, gdzie zainteresowana osoba musi zasięgnąć odpowiedniej porady prawnej, aby dokonać oceny, w stopniu rozsądnym w danych okolicznościach, konsekwencji, jakie dane działanie może za sobą pociągać. Natomiast konstrukcja art. 115 ust. 3 pr. aut. nie spełnia wymogów „przewidywalności” z przyczyn opisanych powyżej. Rodzi to pytanie o zasadność utrzymania tej regulacji, w odniesieniu do której można wskazać tak liczne wątpliwości interpretacyjne, co w konsekwencji przekłada się na praktyczne stosowanie tego przepisu. Wątpliwości tych nie rozwiało przytoczone na wstępie orzeczenie Trybunału Konstytucyjnego. Uzasadniona wydaje się wobec tego teza, że skoro ustawodawca zdecydował się chronić autorskie prawa osobiste wskazane w art. 16 pr. aut., to warto rozważyć dokonanie zmiany ust. 3 art. 115 pr. aut. Należy bowiem wskazać, że art. 115 ust. 1 i 2 pr. aut. czynią zadość zasadzie określoności, a w konsekwencji ustalenie zachowań penalizowanych przez te przepisy nie powoduje trudności - w przeciwieństwie do ust. 3 tego przepisu. Wobec powyższego wydaje się uzasadnione dokonanie takiej zmiany ust. 3, która w sposób niewątpliwy wskazywałaby na te naruszenia autorskich praw osobistych, które ustawodawca chce chronić, zwłaszcza że autorskie prawa osobiste chronią więź twórcy z utworem, która jest kategorią niedookreśloną. Należałoby zatem zrezygnować z tak szerokiego i niejasnego odesłania, wskazując w to miejsce konkretne naruszenia autorskich praw majątkowych, które podlegałyby ochronie prawnokarnej, wskazując jednocześnie konkretne czynności czasownikowe takich czynów.

konkretny przepis karny zapisany w ustawie. Dla przyjęcia bezprawności czynu nie jest więc konieczne ustalenie, że sprawca znał treść ustawowych znamion czynu zabronionego, gdyż wystarczy ustalenie, że uświadamia sobie, że czynem swym naruszył przewidzianą regułę postępowania, do której przestrzegania był zobowiązany" (zob. wyrok SN z 7 V 2002 r., sygn. II KK 39/02, LEX nr 53316).

${ }^{40}$ Wyrok ETPC z 15 VII 2014 r. w sprawie Ashlarba v. Gruzja, skarga nr 45554/08, LEX nr 1483491. 


\section{THE OFFENCE OF VIOLATION OF AUTHOR'S MORAL RIGHTS UNDER ARTICLE 115 PARA. 3 OF THE ACT OF 4 FEBRUARY 1994 ON COPYRIGHT AND RELATED RIGHTS}

\section{Sum mary}

The Act of February 4, 1994 on Copyright and Related Rights, which regulates issues related to the protection of copyrights, belongs to the private law system (its provisions protect the private interest). However, the Act includes both administrative and criminal law provisions aimed at protecting the public interest. The literature rightly points out that the systemic division into public and private law is becoming increasingly less pronounced, due to the permeation of legal domains belonging to both systems. An example of such interpenetration are the provisions of copyright law. This statement is significant for the considerations made in this article due to the statutory method of penalising certain behaviour contained in the provisions of the Copyright and Related Rights Act. Criminal law provisions, systemically related to public law and protecting the public interest, contain references to the provisions of the Copyright and Related Rights Act regulating the scope of copyright protection, i.e. private law norms. In the context of the requirements that should be met by criminal law, such a reference raises doubts, which are particularly highlighted in Art. 115 para. 3 of the Copyright and Related Rights Act. This issue is important because the Constitutional Tribunal in its judgment of 17 February 2015, Ref. $\mathrm{K} 15 / 13$ recognised this provision as constitutional. Therefore, he concluded that the principle of the specificity of a criminal act does not preclude the legislator from using terms that are imprecise or vague if their designations can be determined. At the same time, the Constitutional Tribunal has not presented any arguments indicating that in this case the determination of the designates of Art. 115 para. 3 of the Copyright and Related Rights Act does not cause any difficulties. The author of this article attempts to determine the extent of criminal liability in the event of a violation of author's moral rights (Article 115 section 3 of the Copyright and Related Rights Act), at the same time indicating the difficulties that are associated with the unambiguous determination of behaviour which Art. 115 para. 3 of the Copyright and Related Rights Act penalises.

Keywords: author's moral rights - copyright - criminal liability 